\title{
ETHICAL LEADERSHIP AT WORK AND WORKPLACE WELL-BEING OF EMPLOYEES IN A COAL POWER PLANT
}

\author{
Diosdado A. Ugmares ${ }^{1}$, Victoria O. Ligan ${ }^{2}$, Alberto N. Bandiola ${ }^{3}$ \\ ${ }^{I}$ Master in Public Administration, University of Mindanao, Davao City, Philippines \\ ${ }^{2}$ Doctor of Public Administration, Davao del Sur State College, Digos City, Philippines \\ ${ }^{3}$ Doctor in Public Administration, University of Mindanao, Davao City, Philippines
}

Article DOI: https://doi.org/10.36713/epra9619

DOI No: 10.36713/epra9619

\begin{abstract}
This study proposed that ethical leadership at work and workplace well-being are significantly related and that ethical leadership could also significantly influence workplace well-being. There was a total of 122 samples in this study, which included the rank and file workers and employees in a coal power plant, with the exclusion of the top management. The data were analyzed using descriptive and inferential statistics such as the mean and standard deviation, Pearson $r$, and multiple regression analysis. Results yielded high levels of ethical leadership at work and workplace well-being. Also, the correlation test revealed a significant relationship between the two variables in this study. In addition, the regression analysis revealed a significant influence of ethical leadership on workplace well-being. Finally, the regression models revealed that people-orientation is the best predictor for workplace well-being. The paper offers further discussion of the results.
\end{abstract}

KEYWORDS: ethical leadership at work, workplace well-being, coal power plant, public administration,Philippines

\section{INTRODUCTION}

Leadership affects workers, and unethical leadership negatively influences the workers' well-being. Workers under this leadership are emotionally exhausted and unproductive [1]. More so, when unhealthy working environment pairs with unethical leadership. Workers are emotionally exhausted and physically sick, and others die prematurely [2].

Well-being is one of life's essentials; it is not only the absence of disease or illness. It is an intricate combination of physical, mental, emotional, and social health factors [3]. In addition, happiness and life satisfaction are products of wellbeing. In short, well-being reveals a person's feelings about himself and life [4].

Ethical leadership at work is also known as positive leadership. Research has proven that ethical or positive

\section{OBJECTIVES}

This study mainly sought the significant relationship between its variables and the influence that ethical leadership at work has on the well-being of workers in a coal power plant. leadership strongly correlates with each other [5]. Similarly, [6] found a significant correlation between ethical leadership and well-being, explaining the effect of leadership either in quality of care, work, service, or product.

However, this ethical or positive leadership field is relatively new [7]. In this study's locale, the author has not come across such an investigation. Thus there is a research gap, which makes this study urgent. The findings of this study will shed light on the impacts of ethical leadership at work on the wellbeing and productivity of workers. Not only that, this study will put ethical or positive leadership in its rightful position in the workplace.

In addition, it intended to describe the levels of ethical leadership at work and workplace well-being through the indicators found inside the tables. 


\section{METHODS}

This study was quantitative non-experimental, primarily employing a descriptive-correlational research technique with 122 survey respondents. The survey respondents were the rank and file workers in a coal power plant selected through stratified random sampling [8]. Data were analyzed using the mean and standard deviation, which described the levels of ethical leadership at work and the workplace wellbeing of workers in a coal power plant. Pearson's $r$ determined the significance of the relationship between the variables [9], and regression analysis established the predictors [10] of the workplace well-being of workers in a coal power plant.

\section{RESULTS AND DISCUSSION}

Table 1

Level of Ethical Leadership at Work

\begin{tabular}{|c|c|c|c|}
\hline Indicators & SD & Mean & Descriptive Level \\
\hline People-orientation & 0.53 & 4.03 & High \\
\hline Fairness & 0.63 & 4.05 & High \\
\hline Power Sharing & 0.55 & 4.14 & High \\
\hline Concerns for Sustainability & 0.72 & 3.85 & High \\
\hline Ethical Guidance & 0.55 & 3.99 & High \\
\hline Role Clarification & 0.54 & 3.94 & High \\
\hline Integrity & 0.77 & 3.77 & High \\
\hline Overall & 0.38 & 3.97 & High \\
\hline
\end{tabular}

Table 1 displays supervisors' overall high level of ethical leadership in a coal power plant, as evidenced by an overall mean score of 3.97 with a standard deviation of 0.38 . The score means that the respondents often observed the traits such as people-orientation, fairness, power-sharing, concerns for sustainability, ethical guidance, role clarification, and integrity exhibited by their supervisors in their workplace. These are the crucial aspects of management that employees often want to witness and experience. Moreover, a work environment with such ethical leadership exudes positivity that promotes workers' well-being [5].

Ethical leadership means doing the right thing [11]; [12]. In addition, the leader acts according to the moral principles operating in the workplace [13]. Fairness and integrity, for example, are two of the ethical traits that employees look for in a leader [14] because with these attributes, they could expect transparency and not scandals spreading in the organization [15].

Ethical leadership is a process that does not go out of style [16]. Ethical leaders are wanted in a world with corruption and disloyalty to service, especially in government service [17]. Moreover, where leadership is ethical, members become ethical [18], and the workplace becomes a breeding ground for innovation, productivity, and success [19].

Table 2

Level of Workplace Well-being of Coal Plant Workers

\begin{tabular}{lccc}
\hline \multicolumn{1}{c}{ Indicators } & SD & Mean & Descriptive Level \\
\hline Work Satisfaction & 0.37 & 4.01 & High \\
Organizational Respect for the Employee & 0.46 & 4.07 & High \\
Employee Care & 0.72 & 3.92 & High \\
Intrusion of Work into Private Life Questions & 0.50 & 3.97 & High \\
$\quad$ Overall & 0.32 & 3.99 & High \\
\hline
\end{tabular}


Table 2 shows the data on workplace well-being in a coal power plant. The overall mean score is 3.99 , with a standard deviation of 0.32 means that the respondents are often satisfied with their workplace well-being, namely, work satisfaction, organizational respect for the employee, employee care, and intrusion of work into private life questions. Every indicator of workplace well-being has a high mean score, suggesting that the respondents have agreed that they often experienced the things stipulated in the survey items. For example, organizational respect for the employee (mean $=4.07$; $\mathrm{sd}=0.46$ ) talks about employees trusting the senior people in the organization.

Workplace well-being is a sought-after condition by employees because they all want to be part of an organization offering a workplace imbued with happy and productive workers [20]. In contrast, the opposite workplace causes dissatisfaction among employees, tires the workers, and encourages turnover [21]; [22]

For example, it is vital that employees feel cared for and respected. Once employees are satisfied with how the administration treats them, they become more engaged with improved performance [23]. However, sometimes, there are issues at work that intrude into the private life of workers, challenging the physical, emotional, and cognitive well-being. Some can withstand these challenges and still hope for better outcomes, but some give up [24]. When this happens, the organization must get in the way of remedying the situation.

Workplace well-being is the goal of every organization, in whatever season and condition - even with this pandemic [25]. Moreover, employees need workplace well-being, especially during difficult times, because it balances the opposing forces outside the organization [26].

Table 3

Relationship between Ethical Leadership at Work and Workplace Well-being

\begin{tabular}{|c|c|c|c|c|c|}
\hline & \multicolumn{5}{|c|}{ Workplace Well-being } \\
\hline & $\begin{array}{c}\text { Work } \\
\text { Satisfaction }\end{array}$ & $\begin{array}{c}\text { Organizational } \\
\text { Respect for the } \\
\text { Employee }\end{array}$ & $\begin{array}{c}\text { Employee } \\
\text { Care }\end{array}$ & $\begin{array}{c}\text { The intrusion of } \\
\text { Work into Private } \\
\text { Life Questions }\end{array}$ & Sig. \\
\hline \multicolumn{6}{|l|}{ Ethical Leadership at Work } \\
\hline People-orientation & $\begin{array}{c}.135 \\
(.137)\end{array}$ & $\begin{array}{c}.141 \\
(.121)\end{array}$ & $\begin{array}{l}.696^{* *} \\
(.000)\end{array}$ & $\begin{array}{l}.743^{* *} \\
(.000)\end{array}$ & $\begin{array}{l}.767^{* *} \\
(.000)\end{array}$ \\
\hline Fairness & $\begin{array}{l}.115 \\
(.205)\end{array}$ & $\begin{array}{c}.069 \\
(.453)\end{array}$ & $\begin{array}{l}.774^{* *} \\
(.000)\end{array}$ & $\begin{array}{l}.434^{* *} \\
(.000)\end{array}$ & $\begin{array}{l}.658^{* *} \\
(.000)\end{array}$ \\
\hline Power Sharing & $\begin{array}{c}.077 \\
(.402)\end{array}$ & $\begin{array}{r}-.020 \\
(.826)\end{array}$ & $\begin{array}{l}.480^{* *} \\
(.000)\end{array}$ & $\begin{array}{l}.763^{* *} \\
(.000)\end{array}$ & $\begin{array}{l}.578^{* *} \\
(.000)\end{array}$ \\
\hline Concerns for Sustainability & $\begin{array}{c}.145 \\
(.110)\end{array}$ & $\begin{array}{r}-.032 \\
(.731)\end{array}$ & $\begin{array}{l}.105 \\
(.248)\end{array}$ & $\begin{array}{r}-.017 \\
(.852)\end{array}$ & $\begin{array}{c}.083 \\
(.365)\end{array}$ \\
\hline Ethical Guidance & $\begin{array}{c}.002 \\
(.982)\end{array}$ & $\begin{array}{c}.126 \\
(.166)\end{array}$ & $\begin{array}{l}.458^{* *} \\
(.000)\end{array}$ & $\begin{array}{l}.841^{* *} \\
(.000)\end{array}$ & $\begin{array}{l}.628^{* *} \\
(.000)\end{array}$ \\
\hline Role Clarification & $\begin{array}{c}.015 \\
(.870)\end{array}$ & $\begin{array}{c}.131 \\
(.149)\end{array}$ & $\begin{array}{l}.342^{* *} \\
(.000)\end{array}$ & $\begin{array}{l}.688^{* *} \\
(.000)\end{array}$ & $\begin{array}{l}.509^{* *} \\
(.000)\end{array}$ \\
\hline Integrity & $\begin{array}{c}.020 \\
(.830)\end{array}$ & $\begin{array}{r}-.011 \\
(.901)\end{array}$ & $\begin{array}{c}.001 \\
(.991)\end{array}$ & $\begin{array}{c}.137 \\
(.133)\end{array}$ & $\begin{array}{c}.053 \\
(.563)\end{array}$ \\
\hline Overall & $\begin{array}{l}.120 \\
(.189)\end{array}$ & $\begin{array}{c}.081 \\
(.376)\end{array}$ & $\begin{array}{l}.616^{* *} \\
(.000)\end{array}$ & $\begin{array}{l}.760^{* *} \\
(.000)\end{array}$ & $\begin{array}{l}.702^{* *} \\
(.000)\end{array}$ \\
\hline
\end{tabular}

Sig. at the $p<0.01 * * \& p<0.05 *$ level (2-tailed)

Table 3 shows the correlation test results. The overall coefficient of correlation is .702 , which is significant at a pvalue of <.05. The correlation coefficient conveys a solid and positive relationship between ethical leadership and workplace well-being. It means that the $70.2 \%$ increase in ethical leadership at work would also increase workplace well-being by that level. Moreover, the relationship is two-tailed, meaning it is reciprocal in that whichever increases, one variable also goes with the same increase.

Of the seven indicators of ethical leadership at work, five have significant relationships with workplace well-being; the two indicators, concerns for sustainability and integrity, 
display otherwise. In other words, the correlation coefficients of these two indicators are not substantial enough to establish a significant relationship. However, the associative function of Pearson $r$ showed the linear association of the variables [27].

This result confirms several studies that proved ethical leadership at work and workplace well-being are significantly correlated [28]; [29]; [30]. Furthermore, the elements of ethical leadership at work such as people-orientation, fairness, powersharing, concerns for sustainability, ethical guidance, role clarification, and integrity are also the imperatives of workplace well-being.

For example, people-orientation can result in a positively charged organization [31], affecting workplace wellbeing [32]; [33]. Fairness opens equal opportunities to workers, thereby giving them security and ease in their jobs, ensuing in job satisfaction [34]; [35]; [36]. Workplace well-being happens with fair leadership [37]; power-sharing shows democracy operating in the workplace. Employees are more attuned to democracy for the protection of their rights. Democracy in the workplace breeds employees' well-being [38]; [39].

Further, ethical leaders provide moral guidance to their members by promoting professionalism in the workplace. Professionalism breeds respect, tolerance, and a more effective workplace for diversity and well-being [40]. Role clarification is evident in a professional work setting prevents overlapping or stepping on others' toes to accomplish things. Nevertheless, collaboration among peers happens every time, and employees feel that their opinions, talents, and skills matter in the organization [41].

In sum, employees value how organizations treat them as persons. Therefore, workplace well-being can happen if organizations treat their employees as worthy people rather than a means to their end.

Table 4

Influence of the Ethical Leadership at Work on Workplace Well-being

Ethical Leadership at Work (indicators)

Constant

People-Orientation

Fairness

Power-Sharing

Concerns for Sustainability

Ethical Guidance

Role Clarification

Integrity

$\mathrm{R}$

$\mathrm{R}^{2}$

$\Delta \mathrm{R}$

F

$\rho$
B

1.797

.327

.147

$-.074$

$-.001$

.191

$-.035$

$-.008$

\section{Workplace Well-being}

$\beta$

$t$

10.172

5.878

4.459

$-1.483$

$-.052$

2.467

$-.507$

$-.354$

$-.059$

$-.019$
Sig.

.000

.000

.000

.141

.958

.015

.613
.838
.702
.684
38.394
.000

Table 4 displays the regression analysis of the data. The regression model shows that people-orientation, fairness, and ethical guidance are predictors of workplace well-being. However, of the three, people-orientation has the most influence over workplace well-being, as demonstrated by its huge beta coefficient of .538, significant at $\mathrm{p}<.05$. The coefficient of determination $\left(\mathrm{R}^{2}\right)$ is .702 . It indicates that ethical leadership at work influences workplace well-being by 70.2 percent. The remaining 29.8 of workplace well-being is attributable to other factors outside of this study. The result implies that organizations that desire to increase workplace well-being should put ethical leadership at work at the organization's core. Because, whether they like it or not, ethical leadership at work could influence workplace well-being. As pointed out earlier in the previous discussion, ethical leadership is associated with workplace well-being [27]. 
Surprisingly, power-sharing, which has a significant relationship with workplace well-being, does not significantly impact the latter. In other words, despite the relationship between two variables, this relationship may or may not influence the other variable just like this one. Notably, the Pearson $r$ test is not about cause and effect, but it determines the linear relatedness of the variables, that is, how the variables coincide with each other. Meaning the change in one variable corresponds with the difference in the other variable.

\section{CONCLUSION}

The descriptive statistics showed overall high levels of ethical leadership at work and workplace well-being at a coal power plant, suggesting that there is still room for improvement in both variables. Essentially, the correlation test revealed a solid, positive and significant relationship between ethical leadership at work and workplace well-being, suggesting strongly for upholding ethical leadership in the organization to achieve workplace well-being. In addition, the regression model revealed the predictive capability of ethical leadership at work with its manifest variable, people-orientation, as the prime predictor of the workplace well-being of workers in a coal

\section{REFERENCES}

1. Batz, C. (2018). "How leadership behaviors impact employee well-being." https://www.hrdive.com/news/how-leadershipbehaviors-impact-employee-well-being/530390/

2. Union of Concerned Scientists. (2019). "Coal power plants." https://www.ucsusa.org/resources/coal-power-impacts

3. Davis, T. (2019). "What is well-being? Definition, Types, and Well-being skills. "https://bit.ly/32V9pyg

4. Mental Health Foundation of Australia, State of Victoria. (2018). "Wellbeing."

https://www.betterhealth.vic.gov.au/health/healthyliving/wellbeing

5. Kelloway, K, Weiggand, H., McKee, M., \& Das, H. (2013). "Positive leadership and employee well-being." https://www.researchgate.net/publication/258153224

6. Gillet, N., Fouquereau, E., Coillot, H., Bonnetain, F., Dupont, S., Moret, L., Anota, A., \& Colombat, P. (2018). "Ethical leadership, professional caregivers' well-being, and patients' perceptions of quality of care in oncology."

https://www.sciencedirect.com/science/article/pii/S146238891830 0036

7. Zbierowski, P. (2016). "Positive leadership and corporate entrepreneurship: theoretical considerations and research propositions." Entrepreneurial Business and Economics Review, 4(3), 73-84.

8. Bhardwaj, P. (2019). "Types of sampling in research." Journal of the Practice of Cardiovascular Sciences, 5(3), 157

9. Apuke, O. D. (2017). "Quantitative Research Methods: A Synopsis Approach." Kuwait Chapter of Arabian Journal of Business and Management Review, 6(11), 40-47. https://doi.org/10.12816/0040336

10. Murray, L. L., \& Wilson, J. G. (2021). "Generating data sets for teaching the importance of regression analysis." Decision Sciences Journal of Innovative Education, 19(2), 157-166.
The $F$ value of 38.394 , which is significant at $p<.001$, indicates the predictive capability of ethical leadership at work on workplace well-being. Therefore, the $\mathrm{F}$ ratio rejects the null hypothesis that no domain of ethical leadership at work influences workplace well-being.

This result confirms the findings already conveyed by other researchers on the impact of ethical leadership on workplace well-being [42]; [43]; [44].

power plant. Furthermore, the findings affirmed the foundation theories of this study that ethical leadership, authentic leadership, and prosocial leadership are all imperatives for workplace well-being.

The study concludes that leaders need to revisit the organization's mission statement to redesign the existing approaches already operating in the workplace. Then, they would be able to tailor-fit and add new and relevant leadership approaches to boost workplace well-being to reach the peak measure.

11. Berghofer, D. (2019). "Doing the right thing." http://www.ethicalleadership.com/DoingRightThing.htm

12. Plante, T. G. (2009). "Do the right thing: Whatever it means." https://bit.ly/2Ptyrk7

13. Blackman, A. (2018). "What is ethical leadership? How to be a more ethical leader?” https://business.tutsplus.com/tutorials/whatis-ethical-leadership--cms-31780

14. Duggan, T. (2018). "What are the key elements of ethical leadership?" https://yourbusiness.azcentral.com/key-elementsethical-leadership-organization-8819.html

15. Elvin, C. \& Howard, S. (2019). "Added values: The importance of ethical leadership." https://www.ibe.org.uk/userimages/20130610bitcilmaddedvaluesth eimportanceofethicalleadership.pdf

16. Shakeel, F., Kruyen, P. M., \& Van Thiel, S. (2019). "Ethical Leadership as Process: A Conceptual Proposition." Public Integrity, 21(6), 613-624. https://doi.org/10.1080/10999922.2019.1606544

17. Cullen, J. G. (2020). "Moral Recovery and Ethical Leadership.” Journal of Business Ethics. https://doi.org/10.1007/s10551-020-04658-3

18. Den Hartog, D. N. (2015). "Ethical Leadership." Annual Review of Organizational Psychology and Organizational Behavior. Annual Reviews Inc. https://doi.org/10.1146/annurev-orgpsych032414-111237

19. Javed, B., Khan, A. K., Arjoon, S., Mashkoor, M., \& Haque, A. ul. (2020). "Openness to Experience, Ethical Leadership, and Innovative Work Behavior." Journal of Creative Behavior, 54(1), 211-223. https://doi.org/10.1002/jocb.360

20. Nielsen, K., Nielsen, M. B., Chidiebere, N., Marja, O., Evelina, K. S., Isaksson, K. (2017). "Workplace resources to improve both employee well-being and performance: A systematic review and meta-analysis." https://doi.org/10.1080/02678373.2017.1304463 
21. Oruh, E. S., Mordi, C., Ajonbadi, A., Mojeed-Sanni, B., Nwagbara, U., \& Rahman, M. (2020). "Investigating the relationship between managerial employment relations and employee turnover intention: The case of Nigeria." Employee Relations, 42(1), 5274. https://doi.org/10.1108/ER-08-2018-0226

22. Salleh, A. M. M., Omar, K., Aburumman, O. J., Mat, N. H. N., \& Almhairat, M. A. (2020). "The impact of career planning and career satisfaction on employees' turnover intention." Entrepreneurship and Sustainability Issues, 8(1), 218232. https://doi.org/10.9770/jesi.2020.8.1(14)

23. Pagán-Castaño, E., Maseda-Moreno, A., \& Santos-Rojo, C. (2020). "Wellbeing in work environments." Journal of Business Research, 115, 469-474. https://doi.org/10.1016/j.jbusres.2019.12.007

24. Kettlewell, N., Morris, R. W., Ho, N., Cobb-Clark, D. A., Cripps, S., \& Glozier, N. (2020). "The differential impact of major life events on cognitive and affective wellbeing." SSM - Population Health, 10. https://doi.org/10.1016/j.ssmph.2019.100533

25. Blake, H., Yildirim, M., Wood, B., Knowles, S., Mancini, H., Coyne, E., \& Cooper, J. (2020). "Covid-well: Evaluation of the implementation of supported wellbeing centers for hospital employees during the COVID-19 pandemic." International Journal of Environmental Research and Public Health, 17(24), 122. https://doi.org/10.3390/ijerph17249401

26. Martínez, L., Valencia, I., \& Trofimoff, V. (2020). "Subjective wellbeing and mental health during the COVID-19 pandemic: Data from three population groups in Colombia." Data in Brief, 32. https://doi.org/10.1016/j.dib.2020.106287

27. Kent State University. (2018). "Pearson correlation." Kent.edu. https://libguides.library.kent.edu/SPSS/PearsonCorr

28. Adnan, S. (2019). "Linking Ethical Leadership with Employee Work Outcomes: The Moderating Role of Conscientiousness." Journal of Independent Studies and Research-Management, Social Sciences and Economics, 17(1), 183-196. https://doi.org/10.31384/jisrmsse/2019.17.1.11

29. Ahmed, M. N. (2018). "The Essence of Ethical Leadership and Its Influence in Achieving Employees' Job Satisfaction." Business Ethics and Leadership, 2(3),53-66. https://doi.org/10.21272/bel.2(3).53-66.2018

30. Kalshoven, K., \& Boon, C. T. (2012). "Ethical leadership, employee well-being, and helping the moderating role of human resource management." Journal of Personnel Psychology, 11(1), 60-68. https://doi.org/10.1027/1866-5888/a000056

31. Management Consultancy International. (2015, October 22). "People-orientated leadership is effective leadership." MCI. https://mci.edu.au/people-orientated-leadership/

32. Diwan, A. W. R. B. K. (2018). "People-Oriented Leadership: A Qualitative Exploration in Indian Organizations." International Journal of Science and Research (IJSR), 7(3), 1151-1156. https://www.ijsr.net/archive/v7i3/ART2018892.pdf

33. León, F. R., \& Morales, O. (2018). "Effects of people-oriented leadership and subordinate employability on call center withdrawal behaviors." Revista de Psicologia Del Trabajo y de Las Organizaciones, 34(1), 56-62. https://doi.org/10.5093/jwop2018a7

34. Legacy Business Cultures. (2016, February 9). "Dimensions of leadership: Fairness. Legacy Business Cultures." https://legacycultures.com/dimensions-of-leadership-fairness/
35. Reh, F. J. (2019, August 31). "Being a Fair Manager. The Balance Careers." https://www.thebalancecareers.com/fairnessis-good-management-2275883

36. Lips-Wiersma, M., Haar, J., \& Wright, S. (2020). "The Effect of Fairness, Responsible Leadership and Worthy Work on Multiple Dimensions of Meaningful Work."Journal of Business Ethics, 161(1), 35-52. https://doi.org/10.1007/s10551-018-3967-2

37. Gutierrez, S. (2019). "The mediational roles of engagement and $L M X$ in the relationship between leadership fairness and leadership effectiveness." Dissertation Abstracts International Section A: Humanities and Social Sciences, 79(7-A(E)), http://ovidsp.ovid.com/ovidweb.cgi $? T=J S \& P A G E=$ reference $\& D=$ psyc $14 \& N E W S=N \& A N=2018-21179-227$

38. Agarin, T., \& McCulloch, A. (2020, January 1). "How powersharing includes and excludes non-dominant communities: Introduction to the special issue." International Political Science Review. SAGE Publications Ltd. https://doi.org/10.1177/0192512119873075

39. Cardinali, D. (2019, December 5). "Equity, power-sharing, and renewal of civil society." Stanford Social Innovation Review. https://ssir.org/articles/entry/equity_power_sharing_and_renewal _of_civil_society\#

40. UNESCO. (2016, November 30). "Ethics Guidance." UNESCO. https://en.unesco.org/about-us/ethics-office/guidance

41. Hudson, C. C., Gauvin, S., Tabanfar, R., Poffenroth, A. M., Lee, J. S., \& O'Riordan, A. L. (2017). "Promotion of role clarification in the Health Care Team Challenge." Journal of Interprofessional Care, 31(3), 401-403.

https://doi.org/10.1080/13561820.2016.1258393

42. Huang, N., Qiu, S., Yang, S., \& Deng, R. (2021). "Ethical leadership and organizational citizenship behavior: Mediation of trust and psychological well-being." Psychology Research and Behavior Management, 14, 655-664. https://doi.org/10.2147/PRBM.S311856

43. Mahar, S. A., Hussain, N., Saqib, G., Farooq, S. M., \& Rehman, A. (2021). "Leadership behavior and employees job satisfaction: Working for organizational." Psychology and Education Journal, 58(2), 1092-1103. https://doi.org/10.17762/pae.v58i2.2192

44. Sarwar, H., Ishaq, M. I., Amin, A., \& Ahmed, R. (2020). "Ethical leadership, work engagement, employees' well-being, and performance: a cross-cultural comparison." Journal of Sustainable Tourism, 28(12), 2008-2026. https://doi.org/10.1080/09669582.2020.1788039 